\title{
Experimental identification and in silico prediction of bacterivory in green algae
}

\author{
Nicholas A. Bock ${ }^{1} \cdot$ Sophie Charvet ${ }^{1,2} \cdot$ John Burns $\mathbb{1}^{2,3} \cdot$ Yangtsho Gyaltshen ${ }^{2} \cdot$ Andrey Rozenberg $^{4}$. \\ Solange Duhamel $\mathbb{B}^{1,2,5} \cdot$ Eunsoo Kim $\mathbb{1}^{2}$
}

Received: 10 September 2020 / Revised: 3 January 2021 / Accepted: 18 January 2021 / Published online: 2 March 2021

(c) The Author(s) 2021. This article is published with open access

\begin{abstract}
While algal phago-mixotrophs play a major role in aquatic microbial food webs, their diversity remains poorly understood. Recent studies have indicated several species of prasinophytes, early diverging green algae, to be able to consume bacteria for nutrition. To further explore the occurrence of phago-mixotrophy in green algae, we conducted feeding experiments with live fluorescently labeled bacteria stained with CellTracker Green CMFDA, heat-killed bacteria stained with 5-(4,6dichlorotriazin-2-yl) aminofluorescein (DTAF), and magnetic beads. Feeding was detected via microscopy and/or flow cytometry in five strains of prasinophytes when provided with live bacteria: Pterosperma cristatum NIES626, Pyramimonas parkeae CCMP726, Pyramimonas parkeae NIES254, Nephroselmis pyriformis RCC618, and Dolichomastix tenuilepis CCMP3274. No feeding was detected when heat-killed bacteria or magnetic beads were provided, suggesting a strong preference for live prey in the strains tested. In parallel to experimental assays, green algal bacterivory was investigated using a gene-based prediction model. The predictions agreed with the experimental results and suggested bacterivory potential in additional green algae. Our observations underline the likelihood of widespread occurrence of phago-mixotrophy among green algae, while additionally highlighting potential biases introduced when using prey proxy to evaluate bacterial ingestion by algal cells.
\end{abstract}

These authors contributed equally: Nicholas A. Bock, Sophie Charvet

Supplementary information The online version contains supplementary material available at https://doi.org/10.1038/s41396021-00899-w.

Solange Duhamel

duhamel@arizona.edu

$\triangle$ Eunsoo Kim

ekim1@amnh.org

1 Lamont-Doherty Earth Observatory, Columbia University, Palisades, NY, USA

2 Division of Invertebrate Zoology and Sackler Institute for Comparative Genomics, American Museum of Natural History, New York, NY, USA

3 Bigelow Laboratory for Ocean Sciences, East Boothbay, ME, USA

4 Faculty of Biology, Technion - Israel Institute of Technology, Haifa, Israel

5 Now at Department of Molecular and Cellular Biology, The University of Arizona, Tucson, AZ, USA

\section{Introduction}

Mixotrophic (or phago-mixotrophic) phytoplankton are microorganisms capable of using both autotrophy (i.e., photosynthesis) and phagotrophy (e.g., bacterivory) to obtain the carbon and nutrients required to support cellular processes. Because of their ability to utilize different trophic modes, mixotrophs are unique and important links in marine microbial food webs. The degree to which they utilize autotrophy vs. phagotrophy can have wide-ranging ecological consequences, potentially influencing microbial trophic structure and community stability $[1,2]$ in addition to community primary production and carbon cycling [3].

The occurrence of mixotrophy has been long recognized in dinoflagellates [4], haptophytes [5, 6], cryptophytes [7, 8], and chrysophyceans [9-12]. In addition, there is a growing sense for potential major roles played by green algae in bacterivory in oceanic and other aquatic environments. Bell and Laybourn-Parry [13], for example, reported ingestion of both fluorescently labeled microspheres and DTAF-labeled bacteria in Arctic strains of 
Pyramimonas. Anderson et al. [6] reported ingestion of DTAF-labeled bacteria by cells in two Nephroselmis strains, while McKie-Krisberg et al. [14, 15] reported ingestion of fluorescent microspheres by both pico- and nano-sized green algae. Paasch [16] additionally reported stimulated growth in cultures of Cymbomonas tetramitiformis inoculated with co-cultured bacteria compared to controls.

Accounting for contributions to total bacterivory made by green algae is crucial to understanding aquatic microbial food web structure and functioning. In particular, prasinophytes - a paraphyletic assemblage of green algae often characterized by the presence of organic scale covering on the cell body and flagella-are globally distributed and in some cases may account for the majority of phototrophic cells in picophytoplankton size classes [17-19] across biogeochemically distinct oceanic regions. Moreover, because the ancestors of Chloroplastida (or Viridiplantae)_comprising green algae and land plantswere presumably phagotrophic, the structure, physiology, and genes that characterize green algal bacterivory may also help illuminate the origin and early history of this highly successful group [20]. The discovery that Cymbomonas has a complex feeding structure that includes the duct system (originally suggested to be involved in the transportation of scales to the cell surface) and an acidic spherical compartment where digestion takes place, points to the possibility that other prasinophytes presenting a similar structural organization might also be capable of ingesting bacteria [21].

The objective of this study was to explore bacterivory in early diverging green algae by using a combination of experimental assays and gene-based trophic prediction models. Five prasinophyte strains were selected for feeding assays based on morphology, phylogeny, and/or preliminary in silico prediction results using an earlier version of the trophic model presented in Burns et al. [22]. The selected strains include three pyramimonadophycean strains (Pterosperma cristatum NIES626, Pyramimonas parkeae CCMP726, and Pyramimonas parkeae NIES254); a nephroselmidophycean strain (Nephroselmis pyriformis RCC618); and a mamiellophycean strain (Dolichomastix tenuilepis CCMP3274). The occurrence of bacterivory in these strains was tested via the detection of ingested fluorescently labeled bacteria (FLB) via epifluorescence microscopy and flow cytometry. The combined use of these techniques allowed for both the visual confirmation of ingestion via microscopy in addition to the rapid quantification of changes in cellular fluorescence via cytometry [23]. Further, we explored the potential for phagotrophy in diverse green algae using the gene-based trophic model from Burns et al. [22], utilizing a wealth of existing transcriptome and genome data.

\section{Materials and methods}

\section{Selection of algal strains}

All genera of green algae selected for this study are marine flagellates with scales covering the plasma membrane of the cell body and flagella [24, 25]. Of these, Pterosperma and Pyramimonas are closely related to Cymbomonas, all belonging to the Pyramimonadophyceae; members of which display a duct system or its equivalent that is associated with complex cytoskeletal elements [21, 24, 26]. In addition, Pterosperma was previously shown to endocytose labeled glucans and be positive for acid phosphatase, a conserved component in degradative cellular compartments [27]. P. parkeae CCMP726 and D. tenuilepis CCMP3274 were predicted to be mixotrophs using an earlier version of gene-based models as presented in Burns et al. [22]. Finally, N. pyriformis RCC618 represented a third prasinophyte family, from which other strains (K-0557, K-0556) have been shown to be bacterivorous [6].

\section{Growth of algal strains}

Algal cultures were maintained at $17^{\circ} \mathrm{C}$ on a 12 -h light/dark cycle. Growth irradiance was $\sim 80 \mu \mathrm{E} \mathrm{m}^{-2} \mathrm{~s}^{-1}$ for all cultures. All algal cultures were monoprotistan and grown in the presence of undefined bacterial flora. For cytometry experiments, aliquots of maintenance cultures in midexponential growth were transferred in a 1:10 final dilution to $20 \mathrm{~mL}$ of either $\mathrm{f} / 2$ (hereafter nutrient replete) or $\mathrm{f} / 20$ (hereafter nutrient limited) growth medium. Nutrientreplete media was prepared as described in Guillard [28]. Nutrient-limited media was prepared by diluting nutrientreplete media 1:10 in artificial seawater (ASW). As green algae do not generally require silica, the silica was not added to the growth media. To determine the growth phase of the cultures, in vivo fluorescence measurements were taken at regular intervals using a Turner AquaFluor fluorometer (Turner Designs, San Diego CA). Feeding experiments were conducted when the nutrient-replete treatments were in mid to late exponential growth phase.

\section{Preparation of fluorescently labeled bacteria}

FLB were prepared from cultures of Pelagibaca bermudensis HTCC2601 [29, 30], a widely distributed marine bacterium chosen for its small size (1.2-2.3 $\mu \mathrm{m}$ long) relative to the algal strains used. Bacterial cultures were maintained at $27^{\circ} \mathrm{C}$ in ASW enriched with glucose $(0.2 \%$ w/v) and yeast extract $(0.5 \% \mathrm{w} / \mathrm{v})$. Bacterial cultures were generally in late exponential or stationary growth phase at the time of labeling. To obtain appropriate cell densities for labeling, growth medium was removed from culture flasks using a serological 
pipette, and the remaining bacterial pellet was resuspended in $1 \mathrm{~mL}$ of ASW. P. bermudensis cells are non-motile [29] and precipitated naturally during culture growth, eliminating the need for centrifugation to obtain a cell pellet. Triplicate $1 \mathrm{~mL}$ subsamples of the cell suspension were labeled with $5 \mu \mathrm{L}$ SYBR Green I DNA dye (Thermo Fisher Scientific, Waltham MA; Cat. \# S785) diluted to a final concentration of 1:10,000, and enumerated via flow cytometry. For the preparation of live labeled FLB the initial cell suspension was diluted in ASW to a final cell abundance of $1 \times 10^{9}$ cells mL $\mathrm{m}^{-1}$ and a final volume of $1 \mathrm{~mL}$. The remainder of the initial suspension was then used for the preparation of heat-killed FLB.

Live FLB were prepared by labeling bacterial cells with CellTracker Green CMFDA (Thermo Fisher Scientific, Waltham, MA; Cat. \# C7025): a low toxicity cytoplasmic stain [31]. Working solutions of CellTracker Green CMFDA (hereafter CT) were prepared in accordance with manufacturer guidelines and added to one of the dilute cell suspensions to a final concentration of $10 \mu \mathrm{M}$. The CT-labeled FLB suspension (hereafter CT-FLB) was then vortexed for $1-2 \mathrm{~s}$ and incubated for $3 \mathrm{~h}$ in a water bath at $37^{\circ} \mathrm{C}$. Viability tests conducted with $P$. bermudensis indicated bacterial cells were viable after incubation at $37^{\circ} \mathrm{C}$ (See Supplementary Materials SM1.1 and SM1.2; Supplementary Fig. 1). Heatkilled FLB were labeled with 5-(4,6-dichlorotriazin-2-yl) aminofluorescein (5-DTAF, Thermo Fisher Scientific, Waltham, MA; Cat. \# D16) and prepared as per Sherr et al. [32] and Vazquez-Dominguez et al. [33] (hereafter DTAFFLB). The DTAF-FLB were then vortexed and incubated for $2 \mathrm{~h}$ in a water bath at $60^{\circ} \mathrm{C}$. P. bermudensis viability tests indicated bacterial cells to be no longer viable following incubation at temperatures above $45^{\circ} \mathrm{C}$ (See Supplementary Materials SM1.1 and SM1.2; Supplementary Fig. 1).

To remove excess dye following incubation, each cell suspension was filtered through a $25-\mathrm{mm}$ diameter $0.2-\mu \mathrm{m}$ porosity polycarbonate filter and rinsed $3 \times$ with $1 \mathrm{~mL}$ aliquots of ASW. Each filter was transferred to a microcentrifuge tube with $1 \mathrm{~mL}$ ASW and vortexed for $30 \mathrm{~s}$ to detach cells from the filter. The resulting cell suspensions were then transferred to a sterile microcentrifuge tube and stored at $4{ }^{\circ} \mathrm{C}$ until the start of experiments. When experiments were conducted more than $12 \mathrm{~h}$ after the preparation of FLB, wash steps were repeated immediately before the start of experiments. All experiments were conducted within $24 \mathrm{~h}$ of the preparation of FLB.

\section{Flow cytometric examination of bacterivory by green algae}

All cytometric assays of bacterivory were conducted using a Guava Easycyte flow cytometer (MilliporeSigma, Burlington,
MA). For each algal strain tested, triplicate subsamples were prepared from both nutrient-replete and nutrient-limited culture flasks for two experimental treatments: one inoculated with CT-FLB and one inoculated with DTAF-FLB. To ensure algal cell density did not exceed the maximum number of countable cells by the Guava Easycyte flow cytometer, initial algal cell densities in experimental cultures were enumerated, with subsamples then being prepared in ASW to a final volume of $500 \mu \mathrm{L}$ and final algal density of less than $2 \times 10^{5}$ cells $\mathrm{mL}^{-1}$. Treatments were then inoculated with either CT-FLB or DTAF-FLB to final FLB concentrations at $10-50 \%$ of those for unlabeled bacteria. As a negative control (hereafter CT-FLB + PFA), an additional set of triplicate subsamples from both nutrient-replete and nutrient-limited culture flasks were fixed with $32 \%$ electron microscopy grade paraformaldehyde (PFA) to a final concentration of $4 \% 1 \mathrm{~h}$ prior to inoculation with CT-FLB. Only one replicate was prepared for $P$. parkeae NIES254 and CCMP726 treatments inoculated with DTAF-FLB. All treatments were kept in a bench-top incubator, at the same temperature and light intensity as used in the algal growth chamber, for the duration of experiments.

Algal cell populations were identified and enumerated based on chlorophyll red fluorescence and forward scatter signals. Uptake of FLB by algal cells was inferred from changes in the green fluorescence signal of algal cell populations over $3 \mathrm{~h}$ (Fig. 1; Supplementary Fig. 2). Green fluorescence was measured cytometrically for each subsample prior to inoculation with FLB to determine the maximum baseline green fluorescence of algal cultures ( $\mathrm{GF}_{\text {prior }}$; Supplementary Fig. 2). The duration of experiments was selected based on low ingestion rates in several of the strains used, making it not typically possible to resolve feeding within intervals less than $1 \mathrm{~h}$. Subsamples were then analyzed immediately following inoculation with FLB $\left(t_{0}\right)$ and then at $1-h$ intervals for $3 h\left(t_{1}, t_{2}, t_{3}\right)$. An increase in background fluorescence was observed immediately after addition of FLB for all algal cultures and accounted for by measurements at $\mathrm{t}_{0}$ and then subtracting these values from subsequent times points. For each sample analyzed by flow cytometry, the total algal cell abundance $\left(\right.$ cells $\left._{\text {total }}\right)$ was recorded. The number of cells with green fluorescence exceeding $\mathrm{GF}_{\text {prior }}$, indicating ingestion of labeled prey, was recorded as cells $\mathrm{s}_{\mathrm{fed}}$. The percentage of cells $\mathrm{s}_{\text {total }}$ having ingested FLB $\left(\right.$ per $\left._{\text {fed }}\right)$ was calculated as $\left(\right.$ cells $_{\mathrm{fed}} /$ cells $\left._{\text {total }}\right) \times 100$. The difference between per $_{\text {fed }}$ at $t_{0}$ and per $_{\text {fed }}$ at $t_{3}$ was calculated and expressed as per $_{\Delta}$. Green fluorescence of FLB was measured at $t_{0}$ and $t_{3}$ in CT, DTAF, and CT-FLB + PFA treatments to confirm the stability of FLB fluorescence following fixation (see Supplementary Fig. 3 for representative cytograms). 

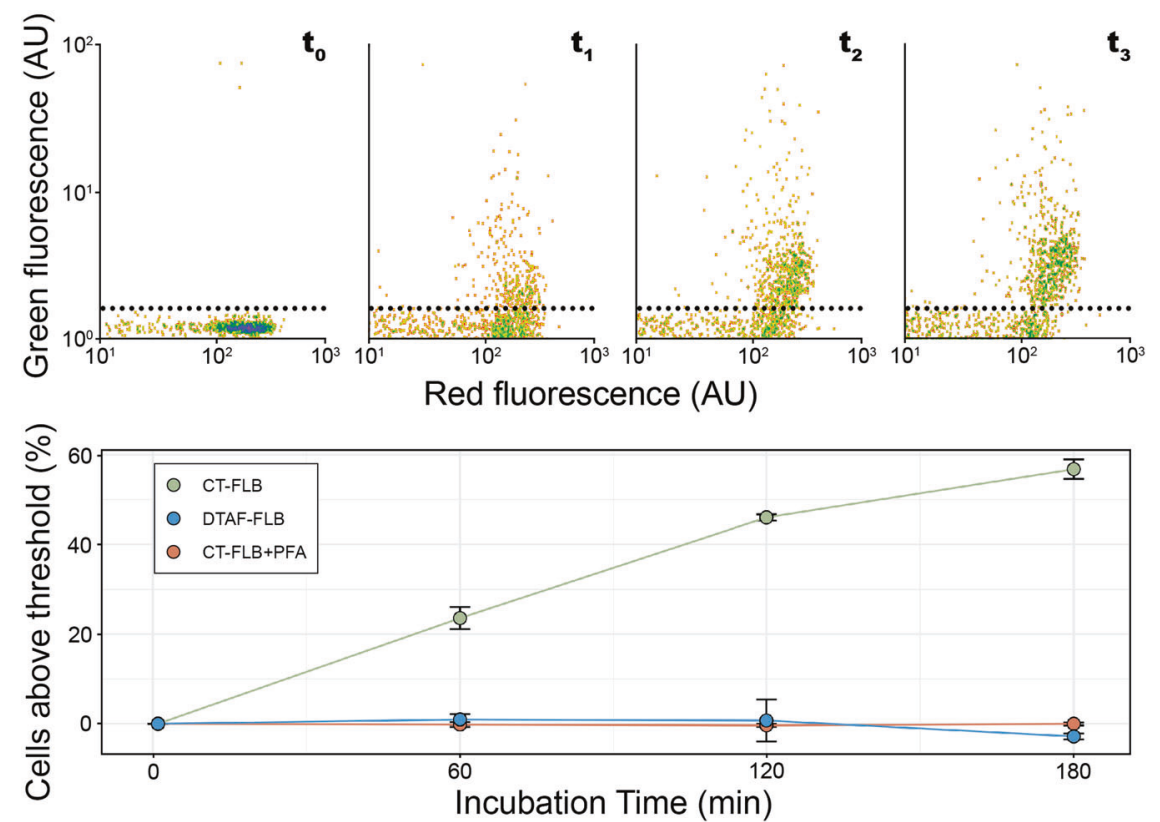

Fig. 1 Example of cytometry results based on experiment conducted with Pterosperma cristatum. Top panel: cytograms corresponding to time points $t_{0}-t_{3}$ in treatment inoculated with CT-FLB. Log-transformed red fluorescence plotted on the $x$-axis in arbitrary units (AU); log-transformed green fluorescence plotted on the $y$-axis in arbitrary units. For clarity, all cytograms were scaled to fill the plotting

\section{Epifluorescence microscopic examination of bacterivory by green algae}

Algal cultures were incubated in $6 \times 8$ multiwell plates (CellTreat Scientific Products, Pepperell, MA) for 15-90 min in the algal growth chamber with concentrations of CT-FLB or DTAF-FLB similar to those in the cytometry experiments described above. The prasinophyte Cymbomonas tetramitiformis PLY262 and haptophyte Diacronema lutheri RCC180, known phago-mixotrophs, were used as general positive controls for FLB ingestion. For strainspecific negative controls to illustrate absence of feeding, the algae were killed in 4\% PFA prior to adding CT-FLB. For strain-specific negative controls to check for possible false staining with residual $\mathrm{CT}$ stain, the algae were inoculated with the $0.2 \mu \mathrm{m}$-filtered supernatant from the last CT-FLB washing step. After incubation, the live algal cells were observed under an epifluorescence microscope (Axiovert $100 \mathrm{M}$, Carl Zeiss, Germany) equipped with filter sets for FITC detection (excitation 470/40, emission 535/40) and chlorophyll detection (excitation 480/30, emission 600LP) to reveal the CellTracker Green or DTAF and natural chlorophyll autofluorescence, respectively. Micrographs were captured with a DP73 camera (Olympus, Japan). The presence of bright green fluorescence inside the algal cell was interpreted as a positive feeding signal. All five prasinophyte strains are characterized by rapid swimming behavior, which, area and centered on the $x$-axis. As such, origin of $x$-axis is $10^{1}$. Dashed line indicates the position of $\mathrm{GF}_{\text {prior }}$. Bottom panel: change in per $\mathrm{fed}_{\mathrm{f}}$ over $180 \mathrm{~min}$ incubation. Colors correspond to prey type used. Green: CT-FLB; blue: DTAF-FLB; red: CT-FLB in sample fixed with PFA $(\mathrm{CT}-\mathrm{FLB}+\mathrm{PFA})$. Error bars correspond to standard error $(n=3)$.

combined with their small cell size, impeded precise counts of ingested bacteria. Furthermore, when exposed to chemical fixatives, including glutaraldehyde, formaldehyde, a mixture of the former two, Lugol's iodine solution and Misky's fixative, the cells would rapidly (within $2 \mathrm{~s}$ ) lose fluorescence and/or show signs of egesting the fluorescent contents of their vacuoles. Therefore, all observations were carried out on live cells and consisted in the qualitative assessment of feeding behavior.

\section{Predictions of phago-mixotrophy using a gene- based model}

Predicted protein data from 19 genome and 71 transcriptome assemblies of green algal species, selected as shown below, were tested for phagocytotic potential using a gene-based model formulated by Burns et al. [22]. The majority of the green algal gene sets used in this study originated from the latest version of transcriptome assemblies generated as part of the Marine Microbial Eukaryote Transcriptome Sequencing Project (MMETSP; doi:10.5281/zenodo.3247846) [34, 35] and the Plant 1000 Transcriptome Project (1KP; http://www. onekp.com/) [35-37]. Coding sequences for all of the transcriptomes were re-annotated using TransDecoder v. 5.5.0 (https://github.com/TransDecoder/TransDecoder). For genome assemblies, whenever gene annotations were not available from the source databases, de novo gene prediction was 
performed with GeneMark-ES v. 4.38 [38] in self-training mode or using models trained on closely related species in case of highly fragmented assemblies. To increase the probability of detecting gene products, protein sets were merged on the level of strains. Completeness of protein sets was assessed with BUSCO v. 4.0.5 [39] against the full eukaryote (odb10) lineage. Only the sets with less than $32 \%$ missing BUSCO genes were kept for the prediction model, except for the Cymbomonas sp. M3265 and Mesostigma viride SAG50-1 transcriptomes, which were kept for the analysis despite missing 33.0 and $41.5 \%$ of eukaryote orthologs, respectively. We also excluded the Aphanochaete repens M2226 protein set showing contaminant sequences matching to a lobose amoeba.

Computational prediction of phagocytotic, photosynthetic, and prototrophic capabilities used the predictTrophicMode tool described in detail in Burns et al. [22]. The code is available at https://github.com/burnsajohn/predictTrophicMode and was run in the default mode after scoring all test genomes and transcriptomes against the hidden Markov models (HMMs) that form the core of the predictTrophicMode tool. Due to broad sampling of eukaryote diversity for the training genomes, the tool is capable of detecting phagocytotic signatures in divergent and novel lineages, such as Mantamonas [22] and the newly discovered Rhodelphis [40]. The predictor is a classifier that was trained by first grouping, by unsupervised clustering, all proteins in 35 complete eukaryote genomes using all vs. all blast followed by MCL clustering. Clusters that satisfied a diversity criterion of containing genes from at least 3 different genomes out of 35 were aligned and converted to HMMs, establishing 14,095 gene models. Individual genes enriched in groups of organisms that share a trophic mode were inferred by grouping the 35 organisms by known trophic capacity for photosynthesis (14 out of 35 organisms), phagocytosis (16 out of 35 organisms), and prototrophy (21 out of 35 organisms). Note that trophic capabilities are not exclusive, organisms could fit into more than one group; see Burns et al. for grouping details [23; Supplementary Table 1]. Enrichment was determined by a significant proportion test [41]. Genes enriched for a trophic capability were clustered by gene ontology (GO) biological processes, and those GO clusters were summarized for each organism using a weighted scoring scheme. The set of the most predictive GO categories was determined using the Boruta algorithm for feature selection [42]. Predictions are called using a probability neural network, trained using the known trophic capabilities of the 35 training genomes, which outputs a numerical probability that a new organism will exhibit each capability [43].

Regarding green algae, the tool used three chlorophycean green algal genomes during training, scoring as photo-autotrophs, Chlamydomonas reinhardtii, Chlorella variabilis, and Volvox carteri, as well as one prasinophyte, Cymbomonas tetramitiformis, scoring as a phago-mixotroph. The prediction outputs were visualized by mapping four dimensions with three degrees of freedom (phagocytosis, photosynthesis, prototrophy, and a fourth dependent dimension for absence of each trophic mode) into color space using scripts modified from the R package "pavo" [44] and projecting the 4D data onto a 2D circular Mollweide projection as described in Jimenez et al. [45].

\section{Statistics}

One-tailed Student's $t$-tests were used to identify significant differences between average per $_{\Delta}$ values in CT treatments and those in CT-FLB + PFA treatments. Shapiro-Wilk tests were performed to confirm the normality of per $_{\Delta}$ values for each treatment. $F$-tests were performed to evaluate the homogeneity of variance between $\operatorname{per}_{\Delta}$ values for CT and CT-FLB + PFA treatments for each strain. One-tailed Welch's $t$-tests were used in instances where the assumption of homogeneity of variance was not met. A significance threshold of $p \leq 0.05$ was used for all tests. All averages are reported \pm standard deviation. All analyses were performed in R Studio [46].

\section{Results}

\section{Feeding experiments measured by flow cytometry}

Results of cytometry feeding experiments are summarized in Fig. 2. The average per $_{\Delta}$ value in the CT-FLB + PFA

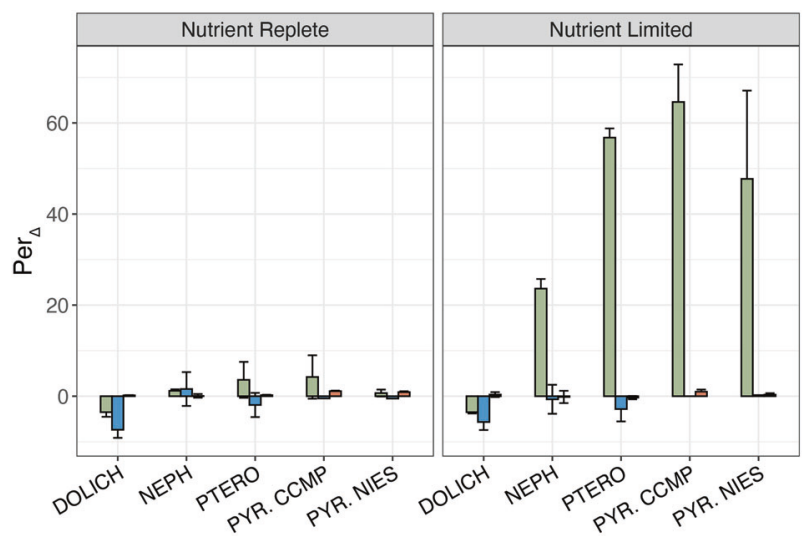

Fig. 2 Values for per $_{\Delta}$ for algae fed with CT-FLB (green), DTAFFLB (blue), or CT-FLB + PFA (red). The left plot corresponds to nutrient-replete treatments and the right plot corresponds to nutrientlimited treatments. DOLICH Dolichomastix tenuilepis, NEPH Nephroselmis pyriformis, PTERO Pterosperma cristatum, PYR. CCMP Pyramimonas parkeae CCMP726, PYR. NIES Pryamimonas parkeae NIES254. Error bars correspond to standard deviation of results for triplicate subsamples of a single culture flask. Negative results for $D$. tenuilepis may be attributed to its low ingestion rate plus photobleaching of extracellular fluorophores over the incubation period (See Supplementary Fig. 4). 


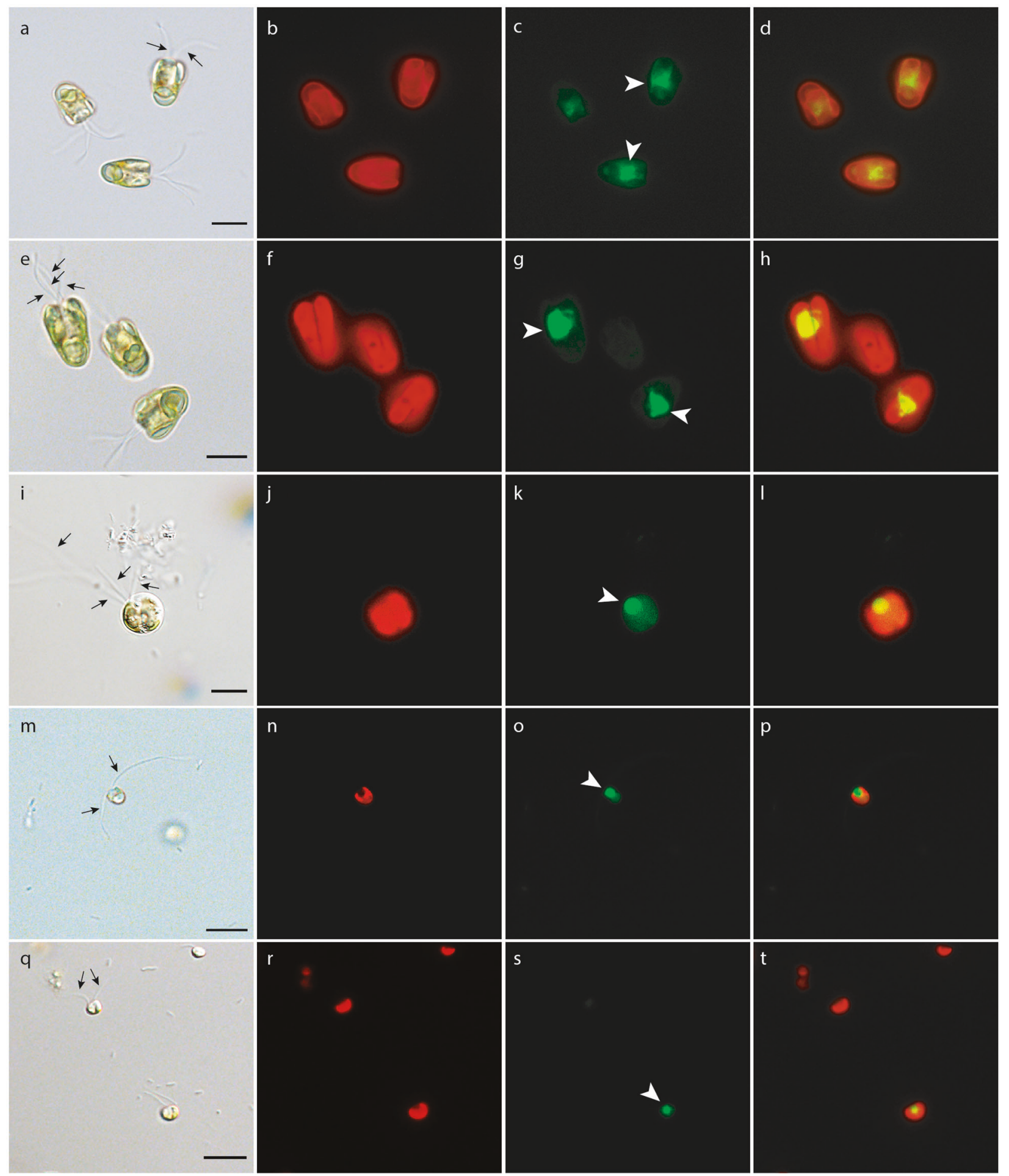

Fig. 3 Epifluorescence microscopic observation of bacterivory in green algae. Light microscopy images of Pyramimonas parkeae NIES254 (a-d), Pyramimonas parkeae CCMP726 (d-h), Pterosperma cristatum NIES626 (i-l), Nephroselmis pyriformis RCC618 $(\mathbf{m}-\mathbf{p})$, and Dolichomastix tenuilepis CCMP3274 (q-t). The prasinophyte cells were fed with CT-FLB. The characteristic shape of the cells with their flagella (black arrows) were captured with the differential interference contrast optic (a, e, i, m, q). Red shows autofluorescence

from the chloroplasts $(\mathbf{b}, \mathbf{f}, \mathbf{j}, \mathbf{n}, \mathbf{r})$. The green spots localized centrally or close to the base of the flagella (white arrow heads), observed with FITC fluorescence, indicate ingestion of fluorescently labeled prey $(\mathbf{c}, \mathbf{g}, \mathbf{k}, \mathbf{o}, \mathbf{s})$. An overlay of FITC and chlorophyll fluorescence images indicates the relative localization of the feeding compartment within the cells $(\mathbf{d}, \mathbf{h}, \mathbf{l}, \mathbf{p}, \mathbf{t})$. Scale bars: $10 \mu \mathrm{m}$. See Supplementary Figs. 5-9 for additional images. 
samples (i.e., PFA-killed, negative controls) across all strains tested was $0.4 \pm 0.70 \%(n=30)$ after $3 \mathrm{~h}$ of incubation. The average $\operatorname{per}_{\Delta}$ value in samples inoculated with heat-killed prey bacteria (DTAF-FLB) across all strains tested was $-2.6 \pm 3.3 \%(n=22)$. The average per $_{\Delta}$ value for nutrient-replete treatments inoculated with CT-FLB was $4.3 \pm 10.2 \%$. Average $\operatorname{per}_{\Delta}$ values for nutrient-limited treatments inoculated with CT-FLB were $23.6 \pm 2.10 \%$ for N. pyriformis; $56.79 \pm 2.00 \%$ for $P$. cristatum; $64.6 \pm 8.23 \%$ for $P$. parkeae CCMP726; $47.7 \pm 19.38 \%$ for $P$. parkeae NIES254; and $-3.5 \pm 0.29 \%$ for D. tenuilepis. The negative values for D. tenuilepis, which nonetheless was observed to ingest CT-FLB by epifluorescence microscopy, may be attributable to photobleaching of background fluorescence over the course of the incubation (Supplementary Fig. 4). $\mathrm{Per}_{\Delta}$ values were significantly greater in nutrient-limited treatments inoculated with CT compared to those inoculated with CT-FLB + PFA for $N$. pyriformis (Student's $t$-test, $p=0.0001$ ), $P$. cristatum (Welch's $t$-test, $p=0.0002$ ), $P$. parkeae CCMP726 (Welch's $t$-test, $p=0.007$ ), and $P$. parkeae NIES254 (Welch's $t$-test, $p=0.02$ ). Per $_{\Delta}$ values for treatments inoculated with CT were not significantly different compared to $\operatorname{per}_{\Delta}$ values for those inoculated with CT-FLB + PFA in nutrient-limited D. tenuilepis treatments, nor in any nutrient-replete treatments. There were no significant changes in the average green fluorescence of FLB between $t_{0}$ and $t_{3}$ for CT-FLB, DTAF-FLB, or CT-FLB + PFA (Student's $t$-test, $p>0.05$ for all comparisons). Therefore, feeding results were assumed to not have been biased by changes in the fluorescence of FLB over the course of incubations.

\section{Feeding experiments observed by microscopy}

Epifluorescence microscopic observation of algal cultures fed with CT-FLB revealed positive feeding signals in all five tested strains, even D. tenuilepis (Fig. 3; Supplementary Figs. 5-9), but no evidence of ingestion was observed with the DTAF-FLB (not shown). One or two bright green fluorescent spheres were clearly visible in cells of the two P. parkeae strains (Fig. 3a-c for NIES254; Fig. 3d-f for CCMP726). When $P$. cristatum was inoculated with CTFLB, we observed a fluorescing sphere that was notably brighter and bigger than the naturally green autofluorescent spot of unknown origin (Fig. $3 \mathrm{~g}-\mathrm{i}$ ). Some $P$. cristatum cells exhibited two fluorescent spheres indicative of feeding compartments (not shown). Ingestion of CT-FLB was also observed for $N$. pyriformis (Fig. 3j-1) and D. tenuilepis by epifluorescence microscopy (Fig. 3m-o). Confocal microscopic observations (Supplementary Materials SM2) indicated that the green fluorescence was located centrally, lodged between the lobes of the chloroplast and directly under the flagellar pit in $P$. parkeae NIES254
(Supplementary Fig. 10a) and at or under the base of the flagellar pit for the other green algal strains (Supplementary Fig. 10b-d). In contrast to feeding experiments with CT-FLB, we did not find a clear indication of magnetic bead ingestion by any of the algal strains (Supplementary Materials SM3).

\section{Predictions of phago-mixotrophy using a gene- based model}

The predictive model identified 17 out of 90 green algal strains as phago-mixotrophic while most of the green algae clustered as photo-autotrophs and one strain was predicted to be a strict osmotroph, a prototroph that lacks both photosynthesis and phagocytosis (Fig. 4; Supplementary Fig. 11). The prediction scores represent the probability that a given organism is capable of the function being tested on a scale of 0 to 1 . A probability greater than 0.5 is interpreted as evidence that the organism can carry out a given function, with higher scores suggesting increased confidence in the functional prediction. Prediction scores for all 90 strains are provided in full detail in Supplementary Table 1. All nine strains of Pyramimonadophyceae surveyed, representing the three genera Cymbomonas, Pterosperma, and Pyramimonas, were predicted to be phago-mixotrophs with high phagocyte scores $(>0.64)$. In addition, the two Nephroselmidophyceae strains tested in the model also consistently showed high phagocyte prediction scores, albeit scoring lower than the phago-mixotrophic Pyramimonadophyceae, with 0.519 for Nephroselmis olivaceae CCAC0105 and 0.542 for N. pyriformis CCMP717. Within the Mamiellophyceae, only two species scored high on phagocyte predictions: D. tenuilepis CCMP3274 and M1680 (both with a score greater than 0.9) and Crustomastix stigmatica CCMP3273. The other mamiellophyceans with the exception of two Mantoniella strains were predicted as non-phagotrophs with scores below 0.05 . Mantoniella antarctica and $M$. beaufortii received prediction scores of 0.43 and 0.22 , respectively. In addition, two chloropicophycean strains, Chloropicon primus CCMP1205 and Chloropicon laureae CCMP2175 were predicted as phago-mixotrophs, scoring 0.707 and 0.979 , respectively, as well as the basal streptophyte Mesostigma viride NIES296 with 0.764. Interestingly, other strains of Chloropicon and Mesostigma scored comparatively lower in phagocyte predictions, e.g., Chloropicon mariensis RCC998 (0.002) and C. roscoffensis CCMP1998, RCC1871, and RCC2335 (0.109, 0.002, and 0.007, respectively), and Mesostigma viride SAG50-1 (0.006) and NIES995 (0.323). All of the strains mentioned above consistently scored high for photosynthesis and prototrophy predictions (Supplementary Table 1). As expected, Polytomella parva SAG63-3, a colorless freshwater flagellate 


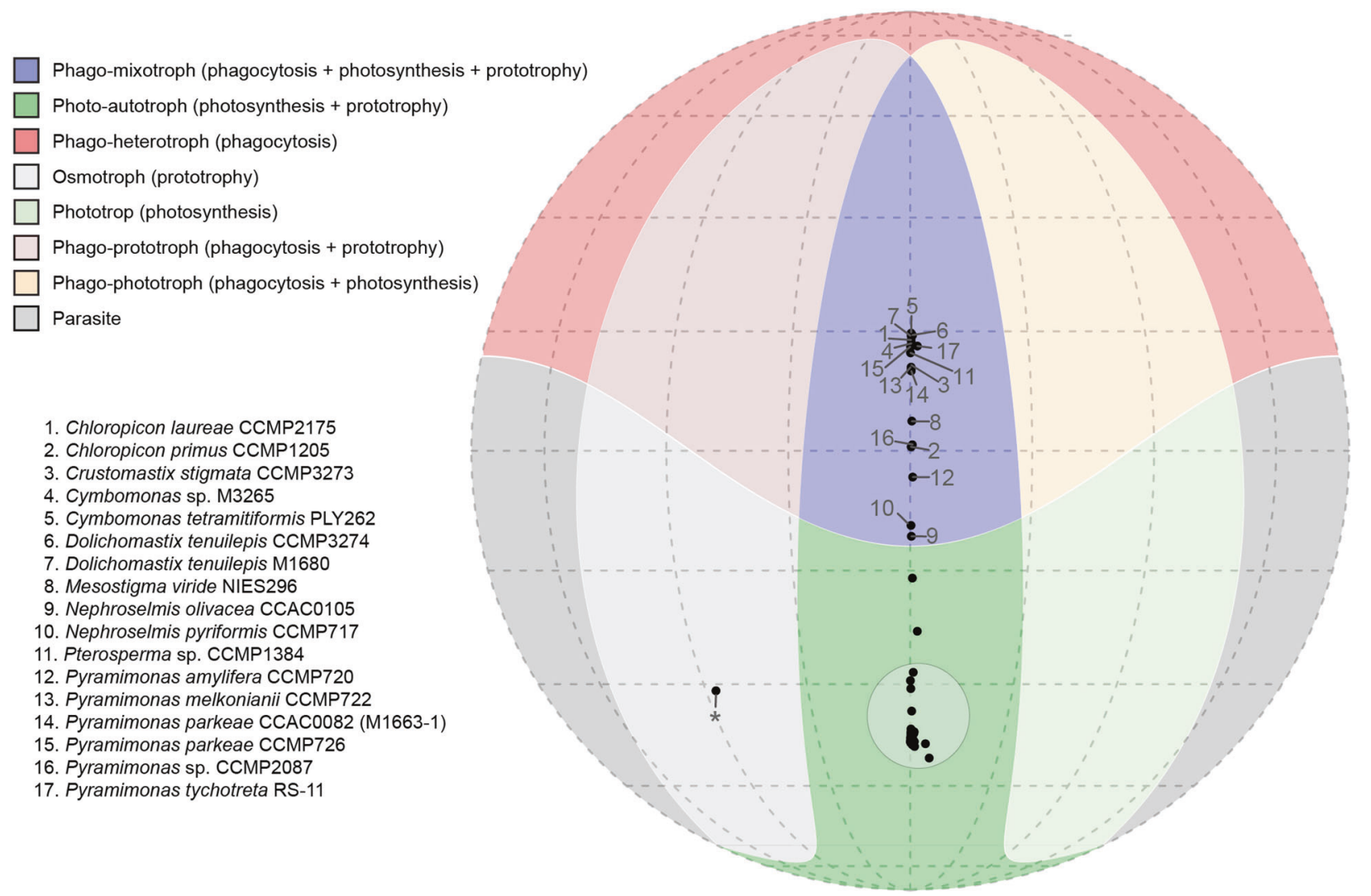

Fig. 4 Mollweide projection showing the 4D positioning of the combination of predictions for phagocyte, prototrophy, and photosynthesis. Dark-colored regions indicate overlapping areas where individual predictions were $>0.50$. Gray regions indicate areas where all three predictions were $<0.50$. Trophic mode categories are based on the combinations of predicted capabilities. Each black dot indicates one of the 90 strains tested with the gene-based model. Numbered strains indicate the green algal strains predicted to be

with a vestigial plastid [47, 48], was predicted as an osmotroph, with a high prototroph score (0.967) but low phagocyte (0.002) and phototroph scores (0.157).

\section{Discussion}

Our experimental results demonstrate the occurrence of bacterivory across all of the prasinophyte strains tested, spanning three prasinophyte groups: the Pyramimonadophyceae, the Nephroselmidophyceae, and the Mamiellophyceae. The strains, chosen for the feeding experiments in this study, sample a deeper range of diversity within the prasinophytes (Fig. 5). Among the Pyramimonadophyceae, we chose $P$. parkeae NIES254 and CCMP726, two strains isolated from different sides of the Pacific Ocean, off the coast of Japan and Monterey Bay, respectively. P. cristatum NIES626, also isolated in Japan, is the first species of this genus to be confirmed as a bacterivore thus confirming the earlier speculations based on ultrastructural studies [20, 21, 24]. phago-mixotrophic. The vast majority of the surveyed taxa fall within the shaded circle (70 in total) in the green photo-autotroph region. An asterisk indicates the prediction for Polytomella parva SAG63-3. Note that of these 90 algae, Cymbomonas tinamiformes PLY262, Chlamydomonas reinhardtii, and Volvox carteri were used in the training sets, coded as a phago-mixotroph or a photo-autotroph, during the formation of the in silico prediction model [22]. Refer to Supplementary Table 1 for more detailed information.

N. pyriformis RCC618, which represents the Nephroselmidophyceae (clade III), was isolated from the Gulf of Mexico at the Galveston Channel station and is a different strain from the species investigated for bacterivory by Anderson et al. [6], K-0557. D. tenuilepis CCMP3274, isolated from the Gulf of Naples, Mediterranean Sea, belongs to the Mamiellophyceae (clade II).

Results from microscopy revealed a green fluorescing compartment within the cells of all five algal strains following inoculation with CT-FLB. Flow cytometry detected significant increases in $\operatorname{per}_{\Delta}$ for all nutrient-limited treatments inoculated with CT-FLB compared to CT-FLB + PFA controls, with the exception of $D$. tenuilepis. No significant differences in per $_{\Delta}$ values were observed for nutrient-replete treatments inoculated with CT-FLB compared to CT-FLB + PFA controls. It seems unlikely that significant increases in $\operatorname{per}_{\Delta}$ were due to factors other than the ingestion of fluorescently labeled prey. The immediate increase in green fluorescence signal observed for all strains with flow cytometry, presumably due to excess extracellular 
Fig. 5 Summary diagram of phago-mixotrophy detected among the green algae. Details of phylogenetic relationships for the core chlorophytes and prasinophytes, in addition to branching phylogenies for streptophytes, are based on previous studies [51, 91-93]. Red stars indicate the clades with experimentally validated mixotrophic representatives, including Cymbomonas [20]; Dolichomastix [this study]; Nephroselmis [14, this study]; Pyramimonas [16, 48, this study]; and Pterosperma [this study]. Gray stars indicate the clades with representatives, such as Crustomastix and some strains of Chloropicon and Mesostigma, that are predicted as phagotrophs by our genebased analyses.

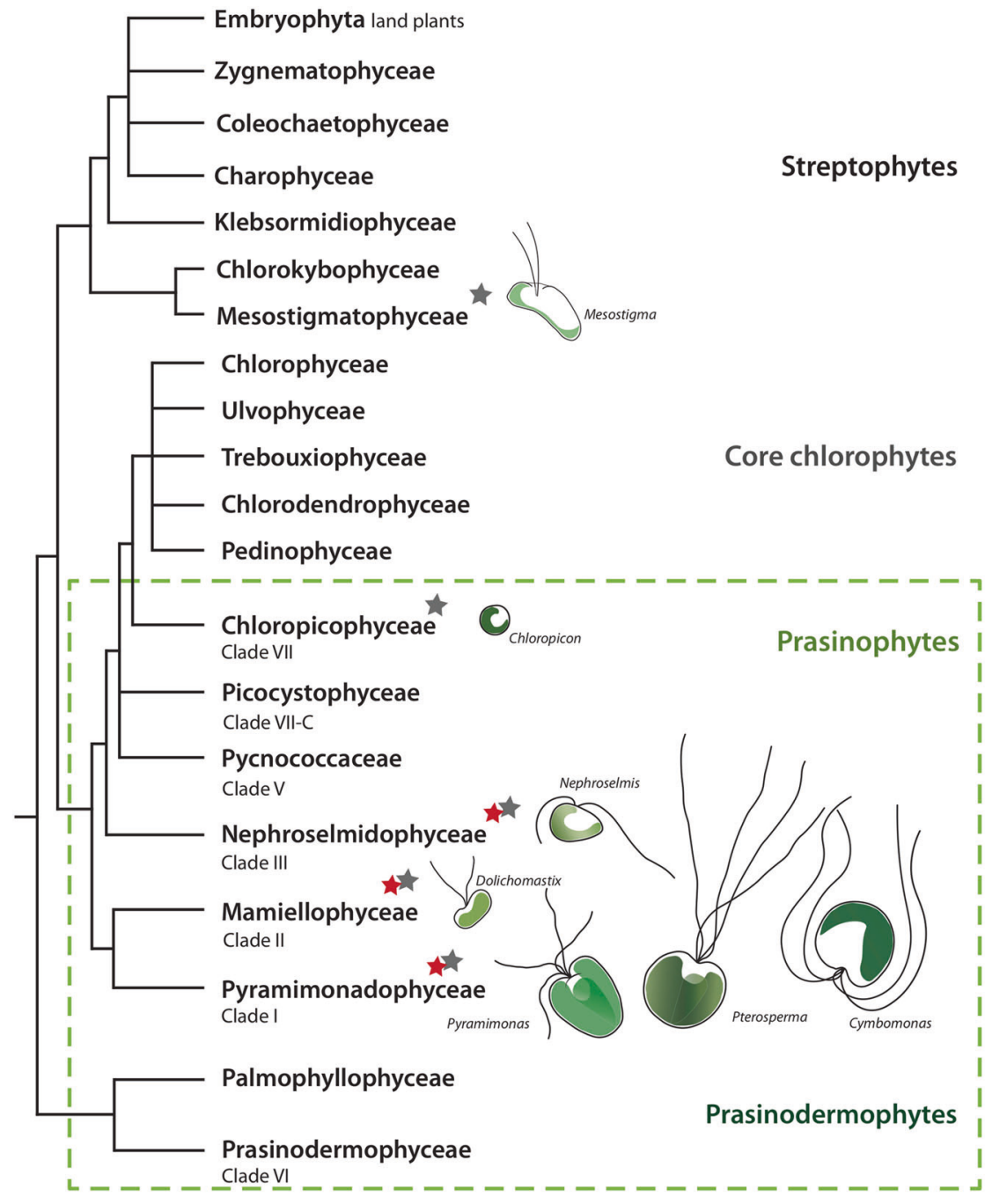

fluorophores in the FLB cell suspensions, was accounted for in $\mathrm{per}_{\Delta}$ estimates. However, given the limited photostability of fluorescein dyes, such as CellTracker CMFDA and DTAF [49], exposure of extracellular fluorophores to light during incubation may have diminished the intensity of background fluorescence over time. Hence, the fluorescence measured likely reflected both increases in algal cell fluorescence due to the ingestion of labeled prey and decreases in background fluorescence due to the photobleaching of extracellular fluorophores (Supplementary Fig. 4a). In cases where ingestion rates are low, this phenomenon may result in net negative per $_{\Delta}$ values (Supplementary Fig. 4b), as were observed in some nutrient-replete treatments and across all $D$. tenuilepis experiments.

Green algae, including prasinophytes, were traditionally considered as strict phototrophs [50, 51], despite several earlier studies that suggested the potential phagotrophic behavior in some prasinophytes [13, 21, 52-55]. More recently, there has been a resurgence of research on bacterivory by green algae, including Cymbomonas tetramitiformis, Micromonas sp. CCMP2099 [15 but see 45], Pyramimonas tychotreta, and Mantoniella antarctica [15], as well as $N$. pyriformis (K-0557) and $N$. rotunda (K-0556) [6]. The current study further expands the known extent to which bacterivory occurs among green algae. Our gene-based predictive model of phagocytosis, in particular, suggested a potential for bacterivory in several green algal genera, distributed in five distinct green algal sub-lineages (Fig. 4). The predictions themselves are not determinate; they use gene content from genomic or transcriptomic data to suggest the capacity for phagocytosis. They also do not specify a set of genes that an organism must have to be considered a phagocyte, but rather determine that an organism has a subset of characteristic genes consistent with the capacity for a trait. Therefore, the predictions are most powerful when combined with experimentation. Strains of Dolichomastix, Nephroselmis, Pterosperma, and Pyramimonas were identified as bacterivores both by in silico predictions and empirical evidence. Of the five strains that are newly confirmed to be phagotrophic by laboratory 
assays in this study, large-scale genetic data currently exist for $P$. parkeae CCMP726 and Dolichomastix tenuilepis CCMP3274. Therefore, we note that the gene-based model of trophic modes and experimental results concur at least for these two strains.

Furthermore, the model predicted three additional green algal taxa to be phago-mixotrophs, including Chloropicon primus, Crustomastix stigmatica, and Mesostigma viride. The dataset used for Chloropicon primus CCMP1205 is the first complete genome available for the recently characterized Chloropicophyceae [56]. This prediction is particularly surprising in that members of the Chloropicophyceae are small scale-less non-motile cells of $2-3 \mu \mathrm{m}$ [57]. Nonetheless, the genome of Chloropicon primus contains genetic signatures for the formation of both scales and flagella [58]. Therefore, it is possible that this species has a previously undocumented flagellate life stage, where bacterivory may play a role in nutrition. Crustomastix stigmatica is small (3-4 $\mu \mathrm{m}$ long $\times 2 \mu \mathrm{m}$ wide) and bears two flagella. Its cell body is not covered with scales, although hairy scales cover the flagella [59]. In addition, the prediction of phagomixotrophy for the genome of the freshwater $M$. viride NIES296 [60], an early diverging streptophyte, supports the hypothesis that bacterivory was present in the common ancestor of Chloroplastida. In terms of characteristic genes in these species, WASH complex proteins, responsible for recycling of membrane proteins from phagosomes back to the cell surface [61], were present in all three datasets (Supplementary Table 2). A second phagocytotic hallmark, DNase II [62], is found in both Chloropicon primus and Crustomastix stigmata, but is absent from $M$. viride (Supplementary Table 2).

The model predictions provided contrasting predictions for strains of the same species or genus, such as Mesostigma or Chloropicon. One strain or species could be predicted to be phago-mixotrophic while another was positioned as photo-autotroph. The contrasting predictions for Chloropicon species can in part be seen with the WASH proteins where WASH complex subunits 1 and 4 are detected in all datasets, but subunits 2,3 , and 5 are only detected in the two strains that received a positive prediction for phagocytosis, Chloropicon primus CCMP1205 and Chloropicon laureae CCMP2175 (Supplementary Table 2). DNase II was detected in all Chloropicon strains (Supplementary Table 2), regardless of the prediction of phagocytotic capacity, emphasizing the combinatorial nature of the predictions; it is not possible to rely on any one gene or process to make a prediction about phagocytotic capacity. The differential detection of phagocytosis related proteins and resultant contrasting predictions, particularly between strains of the same species, may be attributed to the inherent bias of transcriptomic data in that they reflect protein repertoire expressed in particular physiological conditions.
Alternatively, the contrasting interspecific predictions might reflect recent losses of bacterivory in some green algae. For Mantoniella antarctica, there is discordance between the model prediction and previous experimental results [63]. The contrasting claims are reconcilable when considering that the prediction score of 0.43 attained for this alga, abutting the phago-mixotroph threshold, is likely due to incompleteness of the transcriptome data. Indeed, previous predictions of an earlier annotation of this same MMTESP Mantoniella antarctica transcriptome provided a phagotroph score of 0.09 [45], emphasizing the sensitivity of the model to annotation methods. More experimental and sequencing efforts are needed to clarify these issues. Phago-mixotrophy is a spectrum [64] and our model provides avenues to develop new hypotheses on the genetic basis of contrasting mixotrophic behaviors among closely related taxa.

Synthesizing both empirical and in silico prediction data, it appears that phago-mixotrophy is broadly preserved among early diverging members of green algae. However, despite their recognized abundance in many marine regions [17, 19, 65-67], prasinophyte contribution to bacterivory remains conspicuously undetected in most environmental studies [5]. The global underestimation of prasinophyte bacterivory might hinge on the class they are represented by in a given environment. Chloropicophyceae tend to be prevalent in the open ocean, such as the oligotrophic South Pacific Subtropical Gyre, where they contribute significantly to primary production [19, 57]. Our in silico predictions for Chloropicon primus and C. laureae suggest that members of this class have the potential to feed on bacteria. Coastal prasinophytes are generally represented by the Mamiellophyceae [18, 67]. Our predictions showed phago-mixotrophic potential for some members, including D. tenuilepis and Crustomastix stigmatica, the former of which was also experimentally confirmed to ingest bacteria. However, whether or not other members like Micromonas CCMP2099 are capable of consuming bacteria remains debated [14, 45] and needs to be further investigated. In addition, the limited detection of prasinophyte bacterivory in situ may be attributable to the association of feeding with particular environmental conditions, even for a bacterivorous class, such as the Pyramimonadophyceae for which reports of bacterivory are more frequent from polar systems $[13,63]$.

It is also important to consider methodological sources of bias, such as the source of experimental prey. Many protist predators graze selectively [68-71], with prey size being an important factor. Natural assemblages of marine heterotrophic flagellates and ciliates tend to select larger, actively growing bacterial cells [72-76], with prey size in particular affecting the probability of encounter, the capacity for capture and the nutritional value of the prey [77-79]. Prey 
size might also affect the rate at which prey is digested and decomposed, preventing detection of feeding if ingested prey are digested faster than expected, or if they are egested quickly following ingestion [80-83]. In this study, we observed that $D$. tenuilepis did not ingest a relatively large bacterial prey (Alteromonas macleodii) that was successfully consumed by larger strains, including $P$. cirstatum NIES626 and $P$. parkeae NIES254 and CCMP726 (unpublished data).

In addition to the prey size, other factors also play roles in feeding selectivity, such as release of chemical stimuli, prey motility, biochemical composition, and cell surface compounds [80]. In addition, inert surrogate prey (plastic beads or heat-killed bacteria) have been reported to be less recognizable or ingestible by some protists $[75,80]$, such as the phago-mixotrophic Prymnesium [84] and Dinobryon $[80,84,85]$. Therefore, the apparent preference of the green algal strains for the live over the heat-killed FLBs that we observed in this study may be due to significantly reduced ingestion as a result of denaturing of cell structure and biochemistry in the course of the incubations at $60{ }^{\circ} \mathrm{C}$, required for the DTAF labeling protocol. It may also be the case that binding of DTAF fluorophores to the cell surface prevents algal cells from recognizing the DTAF-FLBs as prey. Because cellTracker is a cytoplasmic stain, this would not be an issue in CT-FLB. Similar to DTAF-FLB, magnetic beads were not ingested by the green algae although the attachment of a bead to the area near the cell's anterior was occasionally observed for $P$. cirstatum NIES626 (data not shown). In previous experiments with $P$. cirstatum NIES626, only limited feeding was observed on pHrodo ${ }^{\mathrm{TM}}$ bacterial particles, which are chemically fixed, further demonstrating potential preference for live prey in the surveyed strains. While we were not able to confirm ingestion of DTAF-FLB or magnetic beads by any of the green algae, feeding on killed prey might have occurred at a frequency below the detection limits of the methods used in this study (Supplementary Materials SM4).

\section{Conclusions}

Small mixotrophic protists enhance carbon transfer within the microbial loop $[3,86]$. Indeed, as they feed on their competitors for inorganic nutrients these small mixotrophs compete with their own predators for prey biomass [87] and possibly constitute a more nutritious food source for higher trophic levels [88, 89]. In addition, mixotrophic protists exhibit versatile feeding behaviors [90], which likely affects the nature of the top-down control on prey communities and on carbon cycling. Our results highlight the prevalence of phago-mixotrophy among early diverging green algae and demonstrate the advantage of using live-stained FLB to assay bacterivory in mixotrophic algae. Contributions of green algal bacterivory to microbial community structure and biogeochemical cycling may have previously been underestimated and require further investigation. Additional research is also needed to experimentally validate in silico predictions of phago-mixotrophy in green algae and to characterize the cell structural basis of green algal bacterivory as well as its regulation in response to environmental change.

Acknowledgements The authors are indebted to Colomban de Vargas, Ian Probert, and Daniel Vaulot for providing access to Roscoff Culture Collection (RCC) strains for preliminary feeding assays conducted at the RCC. We also thank Ashley Yang and Kaleigh Lukacs for assisting with green algal culturing; John Favate and Andres Salazar Estrada for conducting preliminary feeding assays using epifluorescence microscopy; and Andrew K Smith at the Microscopy Imaging Facility at the American Museum of Natural History for help with confocal work; and O. Roger Anderson for helpful comments on the manuscript. This work was supported by the NSF CAREER1453639, NSF OCE-14580950, and Simons Foundation 382790 awards to EK, and NSF OCE- 1458070 award to SD.

\section{Compliance with ethical standards}

Conflict of interest The authors declare that they have no conflict of interest.

Publisher's note Springer Nature remains neutral with regard to jurisdictional claims in published maps and institutional affiliations.

Open Access This article is licensed under a Creative Commons Attribution 4.0 International License, which permits use, sharing, adaptation, distribution and reproduction in any medium or format, as long as you give appropriate credit to the original author(s) and the source, provide a link to the Creative Commons license, and indicate if changes were made. The images or other third party material in this article are included in the article's Creative Commons license, unless indicated otherwise in a credit line to the material. If material is not included in the article's Creative Commons license and your intended use is not permitted by statutory regulation or exceeds the permitted use, you will need to obtain permission directly from the copyright holder. To view a copy of this license, visit http://creativecommons. org/licenses/by/4.0/.

\section{References}

1. Jost C, Lawrence CA, Campolongo F, Van De Bund W, Hill S, DeAngelis DL. The effects of mixotrophy on the stability and dynamics of a simple planktonic food web model. Theor Popul Biol. 2004;66:37-51.

2. Tittel J, Bissinger V, Zippel B, Gaedke U, Bell E, Lorke A, et al. Mixotrophs combine resource use to outcompete specialists: Implications for aquatic food webs. Proc Natl Acad Sci. 2011; 100:12776-81.

3. Ward BA, Follows MJ. Marine mixotrophy increases trophic transfer efficiency, mean organism size, and vertical carbon flux. Proc Natl Acad Sci. 2016;113:2958-63.

4. Hansen PJ, Tillmann U. Mixotrophy among dinoflagellates-prey selection, physiology and ecological imporance. In: Subba Rao DV, editor. Dinoflagellates: classification, evolution, physiology 
and ecological significance. Hauppauge, NY, USA: Nova; 2020; 201-60.

5. Unrein F, Gasol JM, Not F, Forn I, Massana R. Mixotrophic haptophytes are key bacterial grazers in oligotrophic coastal waters. ISME J. 2014;8:164-76.

6. Anderson R, Charvet S, Hansen P. Mixotrophy in chlorophytes and haptophytes - effect of irradiance, macronutrient, micronutrient and vitamin limitation. Front Microbiol. 2018;9:1704.

7. Lewitus AJ, Caron DA, Miller KR. Effect of light and glycerol on the organization of the photosynthetic apparatus in the facultative heterotroph Pyrenomonas salina (cryptophyceae). J Phycol. 1991; 27:578-87.

8. Du YooY, Seong KA, Jeong HJ, Yih W, Rho J-R, Nam SW, et al. Mixotrophy in the marine red-tide cryptophyte Teleaulax amphioxeia and ingestion and grazing impact of cryptophytes on natural populations of bacteria in Korean coastal waters. Harmful Algae. 2017;68:105-17.

9. Caron DA, Porter KG, Sanders RW. Carbon, nitrogen, and phosphorus budgets for the mixotrophic phytoflagellate Poterioochromonas malhamensis (Chrysophyceae) during bacterial ingestion. Limnol Oceanogr. 1990;35:433-43.

10. Holen DA, Boraas ME. Mixotrophy in chrysophytes. Chrysophyte algae. Cambridge, UK: Cambridge University Press; 1995;119-40.

11. Fenchel T. Ecology of heterotrophic microflagellates. II. Bioenerg growth Mar Ecol Prog Ser. 1982;8:225-31.

12. Rottberger J, Gruber A, Boenigk J, Kroth P. Influence of nutrients and light on autotrophic, mixotrophic and heterotrophic freshwater chrysophytes. Aquat Micro Ecol. 2013;71:179-91.

13. Bell EM, Laybourn-Parry J. Mixotrophy in the antarctic phytoflagellate, Pyramimonas gelidicola (Chlorophyta: Prasinophyceae). J Phycol. 2003;39:644-9.

14. McKie-Krisberg ZM, Sanders RW. Phagotrophy by the picoeukaryotic green alga Micromonas: implications for Arctic Oceans. ISME J. 2014;8:1953-61.

15. McKie-Krisberg ZM, Gast RJ, Sanders RW. Physiological responses of three species of Antarctic mxotrophic phytoflagellates to changes in light and dissolved nutrients. Micro Ecol. 2015;70:21-29.

16. Paasch A. Physiological and genomic characterization of phagocytosis in green algae. New York, NY, USA: American Museum of Natural History; 2017.

17. Not F, Latasa M, Scharek R, Viprey M, Karleskind P, Balagué V, et al. Protistan assemblages across the Indian Ocean, with a specific emphasis on the picoeukaryotes. Deep Res Part I Oceanogr Res Pap. 2008;55:1456-73.

18. Shi XL, Marie D, Jardillier L, Scanlan DJ, Vaulot D. Groups without cultured representatives dominate eukaryotic picophytoplankton in the oligotrophic South East Pacific Ocean. PLOS ONE. 2009;4:e7657.

19. Rii YM, Duhamel S, Bidigare RR, Karl DM, Repeta DJ, Church MJ. Diversity and productivity of photosynthetic picoeukaryotes in biogeochemically distinct regions of the South East Pacific Ocean. Limnol Oceanogr. 2016;61:806-24.

20. Maruyama S, Kim E. A modern descendant of early green algal phagotrophs. Curr Biol. 2013;23:1081-4.

21. O'Kelly C. Flagellar apparatus architecture and the phylogeny of 'green' algae: Chlorophytes, Euglenoids, Glaucophytes. In: Menzel D, editor. The cytoskeleton of the algae. Boca Raton: CRC Press; 1992. p. 315-41.

22. Burns JA, Pittis AA, Kim E. Gene-based predictive models of trophic modes suggest Asgard archaea are not phagocytotic. Nat Ecol Evol. 2018;2:697-704.

23. Wilken S, Yung CCM, Hamilton M, Hoadley K, Nzongo J, Eckmann C, et al. The need to account for cell biology in characterizing predatory mixotrophs in aquatic environments. Philos Trans R Soc B Biol Sci. 2019;374:20190090.
24. Inouye I, Hori T, Chihara M. Absolute configuration analysis of the flagellar apparatus of Pterosperma Cristatum (Prasinophyceae) and consideration of Its phylogenetic position. J Phycol. 1990;26:329-44.

25. Bhuiyan MAH, Faria DG, Horiguchi T, Sym SD, Suda S. Taxonomy and phylogeny of Pyramimonas vacuolata sp. nov. (Pyramimonadales, Chlorophyta). Phycologia. 2015;54:323-32.

26. Adl SM, Bass D, Lane CE, Lukeš J, Schoch CL, Smirnov A, et al. Revisions to the classification, nomenclature, and diversity of eukaryotes. J Eukaryot Microbiol. 2019;66:4-119.

27. Burns JA, Paasch A, Narechania A, Kim E. Comparative genomics of a bacterivorous green alga reveals evolutionary causalities and consequences of phago-mixotrophic mode of nutrition. Genome Biol Evol. 2015;7:3047-61.

28. Guillard R. Culture of phytoplankton for feeding marine invertebrates. In: Smith WL, Chanley WH, editors. Culture of marine invertebrate animals. 1975. New York: Plenum Press; 1975. p. 22-60.

29. Cho J-C, Giovannoni SJ. Pelagibaca bermudensis gen. nov., sp. nov., a novel marine bacterium within the Roseobacter clade in the order Rhodobacterales. Int J Syst Evol Microbiol. 2006; $56: 855-9$

30. Thrash JC, Cho J-C, Ferriera S, Johnson J, Vergin KL, Giovannoni SJ. Genome sequences of Pelagibaca bermudensis HTCC2601T and Maritimibacter alkaliphilus HTCC2654T, the type strains of two marine Roseobacter genera. J Bacteriol. 2010; 192:5552-3.

31. First MR, Park NY, Berrang ME, Meinersmann RJ, Bernhard JM, Gast RJ, et al. Ciliate ingestion and digestion: Flow cytometric measurements and regrowth of a digestion-resistant Campylobacter jejuni. J Eukaryot Microbiol. 2012;59:12-19.

32. Sherr BF, Sherr EB, Fallon RD. Use of monodispersed, fluorescently labeled bacteria to estimate in situ protozoan bacterivory. Appl Environ Microbiol. 1987;53:958-65.

33. Vazquez-Dominguez E, Peters F, Gasol JM, Vaqué D. Measuring the grazing losses of picoplankton: methodological improvements in the use of fluorescently labeled tracers combined with flow cytometry. Aquat Micro Ecol. 1999;20:119-28.

34. Leebens-Mack J, Barker M, Carpenter EJ. One thousand plant transcriptomes and the phylogenomics of green plants. Nature. 2019;574:679-85.

35. Wincker P. A thousand plants' phylogeny. Nat Plants. 2019;5: 1106-7.

36. Keeling PJ, Burki F, Wilcox HM, Allam B, Allen EE, AmaralZettler LA, et al. The marine microbial eukaryote transcriptome sequencing project (MMETSP): illuminating the functional diversity of eukaryotic life in the oceans through transcriptome sequencing. PLOS Biol. 2014;12:e1001889.

37. Johnson LK, Alexander H, Brown CT. Re-assembly, quality evaluation, and annotation of 678 microbial eukaryotic reference transcriptomes. Gigascience. 2019;8:1-12.

38. Besemer J. GeneMarkS: a self-training method for prediction of gene starts in microbial genomes. Implications for finding sequence motifs in regulatory regions. Nucleic Acids Res. 2001; 29:2607-18.

39. Simão FA, Waterhouse RM, Ioannidis $\mathrm{P}$, Kriventseva EV, Zdobnov EM. BUSCO: assessing genome assembly and annotation completeness with single-copy orthologs. Bioinformatics. 2015;31:3210-2.

40. Gawryluk RMR, Tikhonenkov DV, Hehenberger E, Husnik F, Mylnikov AP, Keeling PJ. Non-photosynthetic predators are sister to red algae. Nature. 2019;572:240-3.

41. Newcombe RG. Interval estimation for the difference between independent proportions: comparison of eleven methods. Stat Med. 1998;17:873-90. 
42. Kursa M, Rudnicki W. Feature selection with the Boruta package. J Stat Softw. 2010;36:1-13.

43. Chasset PO. Probabilistic neural network for the R statistical language. https://github.com/chasset/pnn. Github. 2013.

44. Maia R, Eliason CM, Bitton P-P, Doucet SM, Shawkey MD. pavo: an $\mathrm{R}$ package for the analysis, visualization and organization of spectral data. Methods Ecol Evol. 2013;4:906-13.

45. Jimenez V, Burns J, Le Gall F, Not F, Vaulot D. No evidence of phago-mixotropy in Micromonas polaris, the dominant picophytoplankton species in the Arctic. J Phycol. 2021. https://doi.org/ 10.1111/jpy.13125.

46. R Core Team. R development core team. R A Lang Environ Stat Comput. Vienna: R Foundation for Statistical Computing; 2016.

47. Figueroa-Martinez F, Nedelcu AM, Smith DR, Reyes-Prieto A. When the lights go out: the evolutionary fate of free-living colorless green algae. N. Phytol. 2015;206:972-82.

48. Nakada T, Misawa K, Nozaki H. Molecular systematics of Volvocales (Chlorophyceae, Chlorophyta) based on exhaustive 18S rRNA phylogenetic analyses. Mol Phylogenet Evol. 2008;48: 281-91.

49. Johnson I. The molecular probes handbook: a guide to fluorescent probes and labeling technologies. 11th ed. Waltham, MA, USA: Life Technologies Corporation; 2010.

50. Leliaert F, Smith DR, Moreau H, Herron MD, Verbruggen H, Delwiche CF, et al. Phylogeny and molecular evolution of the green algae. CRC Crit Rev Plant Sci. 2012;31:1-46.

51. Leliaert F. Green algae: chlorophyta and streptophyta. Reference module in life sciences. Amsterdam, DK: Elsevier; 2019.

52. Parke M, Adams I. The Pyramimonas-like motile stage of Halosphaera viridis Schmitz. Bull Res Counc Isr. 1961.

53. Thorndsen J. Cymbomonas Schiller (Prasinophyceae) reinvestigated by light and electron microscopy. Arch fur Protistenkd. 1988;136:327-36.

54. González JM, Sherr BF, Sherr EB. Digestive enzyme activity as a quantitative measure of protistan grazing: the acid lysozyme assay for bacterivory. Mar Ecol Prog Ser. 1993;100:197-206.

55. Moestrup $\varnothing$, Inouye I, Hori T. Ultrastructural studies on Cymbomonas tetramitiformis (Prasinophyceae). I. General structure, scale microstructure, and ontogeny. Can J Bot. 2003;81:657-71.

56. Turmel M, Lopes dos Santos A, Otis C, Sergerie R, Lemieux C. Tracing the evolution of the plastome and mitogenome in the Chloropicophyceae uncovered convergent tRNA gene losses and a variant plastid genetic code. Genome Biol Evol. 2019;11: 1275-92.

57. Lopes dos Santos A, Gourvil P, Tragin M, Noël M, Decelle J, Romac S, et al. Diversity and oceanic distribution of prasinophytes clade VII, the dominant group of green algae in oceanic waters. ISME J. 2017;11:512-28.

58. Lemieux C, Turmel M, Otis C, Pombert J-F. A streamlined and predominantly diploid genome in the tiny marine green alga Chloropicon primus. Nat Commun. 2019;10:4061.

59. Zingone A, Borra M, Brunet C, Forlani G. Kooistra WHCF, Procaccini G. Phylogenetic position of Crustomatix stigmatica sp. nov. and Dolichomastix tenuilepis in relation to the mamiellales (Prasinophyceae, Chlorophyta). J Phycol. 2002;38:1024-39.

60. Liang Z, Geng Y, Ji C, Du H, Wong CE, Zhang Q, et al. Mesostigma viride genome and transcriptome provide insights into the origin and evolution of Streptophyta. Adv Sci. 2020;7: 1901850.

61. Buckley CM, Gopaldass N, Bosmani C, Johnston SA, Soldati T, Insall $\mathrm{RH}$, et al. WASH drives early recycling from macropinosomes and phagosomes to maintain surface phagocytic receptors. Proc Natl Acad Sci. 2016;113:E5906-15.

62. Shpak M, Kugelman JR, Varela-Ramirez A, Aguilera RJ. The phylogeny and evolution of deoxyribonuclease II: An enzyme essential for lysosomal DNA degradation. Mol Phylogenet Evol. 2008;47:841-54.

63. Gast RJ, McKie-Krisberg ZM, Fay SA, Rose JM, Sanders RW. Antarctic mixotrophic protist abundances by microscopy and molecular methods. FEMS Microbiol Ecol. 2014;89:388-401.

64. Mitra A, Flynn KJ, Tillmann U, Raven JA, Caron D, Stoecker DK, et al. Defining planktonic protist functional groups on mechanisms for energy and nutrient acquisition: Incorporation of diverse mixotrophic strategies. Protist. 2016;167:106-20.

65. Kirkham AR, Lepère C, Jardillier LE, Not F, Bouman H, Mead A, et al. A global perspective on marine photosynthetic picoeukaryote community structure. ISME J. 2013;7:922-36.

66. Moon-van Der Staay SY, Wachter R De, Vaulot D. Oceanic 18 S rDNA sequences from picoplankton reveal unsuspected eukaryotic diversity. Nature. 2001;409:607-10.

67. Worden A. Picoeukaryote diversity in coastal waters of the Pacific Ocean. Aquat Micro Ecol. 2006;43:165-75.

68. Van Hannen EJ, Veninga M, Bloem J, Gons HJ, Laanbroek HJ. Genetic changes in the bacterial community structure associated with protistan grazers. Fundam Appl Limnol. 1999;145:25-38.

69. Jürgens $\mathrm{K}$, Güde $\mathrm{H}$. The potential importance of grazing-resistant bacteria in planktonic systems. Mar Ecol Prog Ser. 1994;112:169-88.

70. Jürgens K, Pernthaler J, Schalla S, Amann R. Morphological and compositional changes in a planktonic bacterial community in response to enhanced protozoan grazing. Appl Environ Microbiol. 1999;65:1241-50.

71. Suzuki M. Effect of protistan bacterivory on coastal bacterioplankton diversity. Aquat Micro Ecol. 1999;20:261-72.

72. Sherr EB, Sherr BF. Significance of predation by protists in aquatic microbial food webs. Antonie van Leeuwenhoek2. 2002; 81:293-308.

73. González J, Sherr EB, Sherr BF. Size-selective grazing on bacteria by natural assemblages of estuarine flagellates and ciliates. Appl Environ Microbiol. 1990;56:583-9.

74. Sherr BF, Sherr EB, McDaniel J. Effect of protistan grazing on the frequency of dividing cells in bacterioplankton assemblages. Appl Environ Microbiol. 1992;58:2381-5.

75. González J, Sherr EB, Sherr BF. Differential feeding by marine flagellates on growing vs starving bacteria, and on motile vs nonmotile bacteria. Mar Ecol Prog Ser. 1993;102:257-67.

76. del Giorgio PA, Gasol JM, Vaqué D, Mura P, Agustí S, Duarte CM. Bacterioplankton community structure: Protists control net production and the proportion of active bacteria in a coastal marine community. Limnol Oceanogr. 1996;41:1169-79.

77. Andersen OK, Goldman JC, Caron DA, Dennett MR. Nutrient cycling in a microflagellate food chain: III. Phosphorus dynamics. Mar Ecol Prog Ser. 1986;31:47-55.

78. Fenchel T. Protistan filter feeding. Prog Protistol. 1986;1:65-113.

79. Epstein S, Shiaris M. Size selective grazing of coastal bacterioplankton by natural assemblages of pigmented flagellates, colourless flagellates and ciliates. Micro Ecol. 1992;23:211-25.

80. Montagnes D, Barbosa A, Boenigk J, Davidson K, Jurgens K, Macek M, et al. Selective feeding behaviour of key free-living protists: avenues for continued study. Aquat Micro Ecol. 2008;53: 83-98.

81. Pfister G, Arndt H. Food selectivity and feeding behaviour in omnivorous filter-feeding ciliates: a case study for Stylonychia. Eur J Protistol. 1998;34:446-57.

82. Boenigk J, Arndt H. Bacterivory by heterotrophic flagellates: community structure and feeding strategies. Antonie Van Leeuwenhoek. 2002;81:465-80.

83. Pickup ZL, Pickup R, Parry JD. Growth of Acanthamoeba castellanii and Hartmannella vermiformis on live, heat-killed and DTAF-stained bacterial prey. FEMS Microbiol Ecol. 2007; $61: 264-72$ 
84. Legrand C, Johansson N, Johnsen G, Borsheim K, Graneli E. Phagotrophy and toxicity variation in mixotrophic Prymnesium patelliferum (Haptophyceae). Limnol Oceanogr. 2001;46:1208-14.

85. Caron DA, Sanders RW, Lim EL, Marrasé C, Amaral LA, Whitney S, et al. Light-depend phagotrophy freshwater mixotrophic chrysophyte Dinobryon cylindricum. Micro. Ecol. 1993;25:93-111.

86. Fenchel T. The microbial loop - 25 years later. J Exp Mar Bio Ecol. 2008;366:99-103.

87. Tittel J, Bissinger V, Zippel B, Gaedke U, Bell E, Lorke A, et al. Mixotrophs combine resource use to outcompete specialists: Implications for aquatic food webs. Proc Natl Acad Sci. 2003; 100:12776-81.

88. Moorthi S, Ptacnik R, Sanders R, Fischer R, Busch M, Hillebrand $\mathrm{H}$. The functional role of planktonic mixotrophs in altering seston stoichiometry. Aquat Micro Ecol. 2017;79:235-45.

89. Katechakis A, Haseneder T, Kling R, Stibor H. Mixotrophic versus photoautotrophic specialist algae as food for zooplankton:
The light: nutrient hypothesis might not hold for mixotrophs. Limnol Oceanogr. 2005;50:1290-9.

90. Weisse T, Anderson R, Arndt H, Calbet A, Hansen PJ, Montagnes D. Functional ecology of aquatic phagotrophic protists - concepts, limitations, and perspectives. Eur J Protistol. 2016;55:50-74.

91. Graham LE, Graham JM, Wilcox WL, Cook ME. Algae. 3rd ed. Madison, WI, USA: LJLM Press; 2016.

92. Guillou L, Eikrem W, Chrétiennot-Dinet M-J, Le Gall F, Massana $\mathrm{R}$, Romari K, et al. Diversity of picoplanktonic prasinophytes assessed by direct nuclear SSU rDNA sequencing of environmental samples and novel isolates retrieved from oceanic and coastal marine ecosystems. Protist. 2004;155:193-214.

93. Lemieux C, Otis C, Turmel M. Six newly sequenced chloroplast genomes from prasinophyte green algae provide insights into the relationships among prasinophyte lineages and the diversity of streamlined genome architecture in picoplanktonic species. BMC Genom. 2014;15:857. 